\title{
Incidental ectopic posterior pituitary in an adult
}

\author{
Tomohiro Tanaka, ${ }_{1}^{1}$ Hiroyuki Koyama, ${ }^{1}$ Daisuke Aotani, ${ }^{1}$ Hirotaka Ohara ${ }^{2,3}$
}

${ }^{1}$ Department of

Gastroenterology and

Metabolism, Nagoya City University Graduate School of Medical Sciences, Nagoya, Japan ${ }^{2}$ Nagoya City Hospital Management Department, Nagoya City, Nagoya, Japan ${ }^{3}$ Department of Communitybased Medical Education, Nagoya City University Graduate School of Medical Sciences,

\section{Correspondence to}

Dr Tomohiro Tanaka;

tttanaka@med.nagoya-cu.ac.jp

Accepted 7 May 2020 Nagoya, Japan

\section{DESCRIPTION}

A 54-year-old woman presented with transient headache underwent CT scan, which revealed a highdensity $6 \mathrm{~mm}$ lesion of the diencephalon (figure 1). Her headache subsided overnight. She was born $1300 \mathrm{~g}$ at 7 months of gestation, but grown healthy except for euthyroid Hashimoto disease and dyslipidaemia. MRI revealed normal-sized anterior pituitary within the sella turcica (figure 2A). However, the stalk was unidentifiable and T1-high-signal corresponding to the neurohypophysis was missing

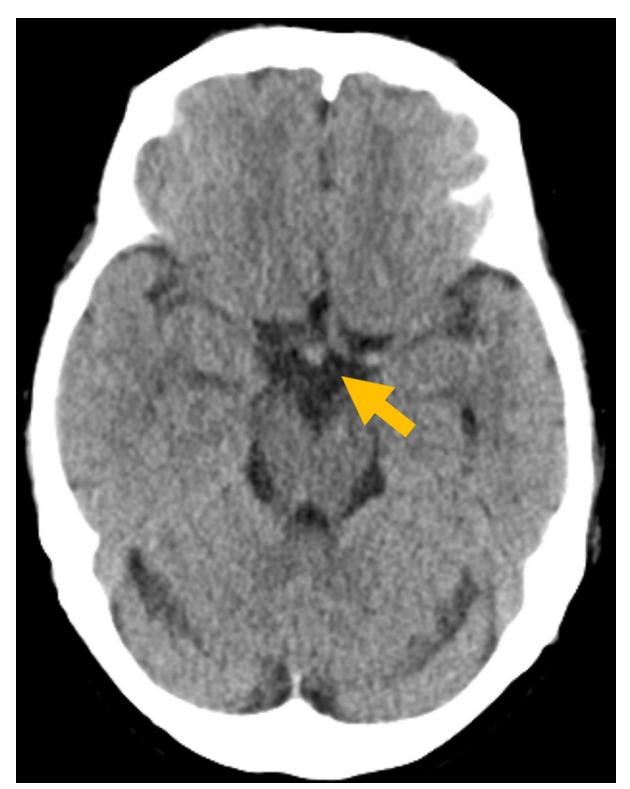

Figure 1 Brain CT scan image without contrast enhancement revealed a nodular region of similar density to brain parenchyma (arrow) anterior to interpeduncular cistern and posterior to optic chiasm.

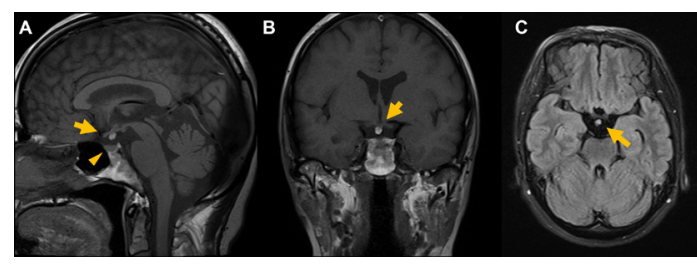

Check for updates

(C) BMJ Publishing Group Limited 2020. No commercial re-use. See rights and permissions. Published by BMJ.

To cite: Tanaka T, Koyama $\mathrm{H}$, Aotani D, et al. BMJ Case Rep 2020;13:e234415 doi:10.1136/bcr-2020234415
Figure 2 MRI scan images. (A) Sagittal view T1weighted image. Soft tissue intensity of normal size was present within the sella turcica (arrowhead), but high intensity signal corresponding to the posterior lobe of the pituitary was absent orthotopically. Pituitary stalk not observed, and T1-high signal was found up at the tip of the infundibulum (arrow). (B) Coronal view T1-weighted image. T1-high signal just beneath the optic stalk (arrow). (C) Axial view fluid attenuation inversion recovery (FLAIR) image. High intensity lesion (arrow) was identified just posterior to the optic chiasm.

\section{Patient's perspective}

I was surprised to hear that my brain is a bit different from the others because I have always thought that I am healthy. But I feel relieved now to hear that the unusual position of a part of my brain is not and may not be causing serious harm to my everyday living.

\section{Learning points}

- Ectopic posterior pituitary may be discovered in brain imaging incidentally in adults.

- Ectopic posterior pituitary may appear as a diencephalic mass in CT scans.

- Screening for anterior as well as posterior pituitary hormones are recommended in incidentally-identified ectopic posterior pituitary.

in situ (figure $2 \mathrm{~A}$ ), but present beneath the median eminence (figure 2A,B). High density lesion visualised by CT scan was also identifiable by the axial view of the MRI study (figure $2 \mathrm{C}$ ). On MRI, the lesion was just posterior to, but not attached to the optic chiasm (figure 2C). Serum and spot urine osmolality, and antidiuretic hormone levels were $288 \mathrm{mOsm} / \mathrm{kg}, 784 \mathrm{mOsm} / \mathrm{kg}$, and $0.6 \mathrm{pg} / \mathrm{mL}$, respectively, arguing against the presence of diabetes insipidus. Anterior pituitary hormones were normal, except insulin-like growth factor-I (IGF-I) (43 ng/ $\mathrm{mL}$, mean $\pm 2 \mathrm{SD}$ : 76-211) without symptoms or signs of growth hormone $(\mathrm{GH})$ deficiency. Serum IgG4 was normal and antipituitary antibodies negative. Blunted stalk with typical T1-high-signal of the posterior pituitary lobe outside the sella supports the diagnosis of ectopic posterior pituitary. ${ }^{1}$ It is a rare condition with or without hypopituitarism. ${ }^{2}$ Perinatal trauma or mutations of the transcription factors regulating pituitary development (HESX1, LHX4, OTX2, SOX3) are reported as aetiology. ${ }^{2}$ The results of the imaging study in this patient remained unchanged 13 months later.

Acknowledgements The authors are grateful to Professor Hiromi Kataoka for supervision and to Ms Aya Nakamura for clerical assistance.

Contributors TT and $\mathrm{HO}$ have been in charge of the patient care. $\mathrm{HK}$ and DA gave advises in clinical management and manuscript preparation as consultant endocrinologists.

Funding The authors have not declared a specific grant for this research from any funding agency in the public, commercial or not-for-profit sectors.

Competing interests None declared. 
Images in...

Patient consent for publication Obtained.

Provenance and peer review Not commissioned; externally peer reviewed.

\section{REFERENCES}

1 Chen S, Léger J, Garel C, et al. Growth hormone deficiency with ectopic

neurohypophysis: anatomical variations and relationship between the visibility of the pituitary stalk asserted by magnetic resonance imaging and anterior pituitary function. J Clin Endocrinol Metab 1999;84:2408-13.

2 Koenig R, Melmed S. Chapter 8 Pituitary Physiology and Diagnostic Evaluation. In: Williams textbook of endocrinology. 13 edn. Elsevier, 2019: 189.

Copyright 2020 BMJ Publishing Group. All rights reserved. For permission to reuse any of this content visit

https://www.bmj.com/company/products-services/rights-and-licensing/permissions/

BMJ Case Report Fellows may re-use this article for personal use and teaching without any further permission.

Become a Fellow of BMJ Case Reports today and you can:

- Submit as many cases as you like

Enjoy fast sympathetic peer review and rapid publication of accepted articles

Access all the published articles

Re-use any of the published material for personal use and teaching without further permission

Customer Service

If you have any further queries about your subscription, please contact our customer services team on +44 (0) 2071111105 or via email at support@bmj.com.

Visit casereports.bmj.com for more articles like this and to become a Fellow 